\title{
PENGARUH KESULITAN KEUANGAN, UKURAN PERUSAHAAN, DAN PIUTANG PADA KONSERVATISME AKUNTANSI
}

\author{
Dian Ayu Anggraeni Kusumadewi \\ STIE Tribuana Bekasi
}

\begin{abstract}
ABSTRAK
Penelitian ini memiliki tujuan untuk mengetahui pengaruh kesulitan keuangan, ukuran perusahaan, dan piutang pada konservatisme akuntansi. Perusahaan Manufaktur yang terdaftar di Bursa Efek Indonesia menjadi populasi pada penelitian ini dengan periode penelitian 2010-2013. Jumlah sampel yang dianalisis sebanyak 241 tahun perusahaan. Sampel diambil dengan metode stratified random sampling. Teknik analisis yang digunakan adalah teknik analisis regresi linier berganda. Hasil penelitian ini menunjukkan bahwa kesulitan keuangan berpengaruh negatif pada konservatisme akuntansi, ukuran perusahaan berpengaruh positif pada konservatisme akuntansi, dan piutang berpengaruh negatif pada konservatisme akuntansi.
\end{abstract}

Kata kunci: Kesulitan keuangan, Ukuran Perusahaan, Piutang, Konservatisme Akuntansi

\section{PENDAHULUAN}

Diakui oleh dunia bahwa bidang usaha kini makin pesat sehingga dapat memicu persaingan diantara para pelaku bisnis. Banyak cara yang bisa dilakukan oleh perusahaan untuk mempertahankan kekuatan dalam perusahaannya. Keadaan perusahaan dapat diperjelas dengan Kinerja keuangan yang tercermin dalam laporan keuangan. Laporan keuangan pada dasarnya merupakan suatu alat yang amat dibutuhkan oleh pihak internal maupun eksternal dalam memperoleh informasi mengenai posisi keuangan perusahaan (Margaretha dan Ramadhan, 2010).

$$
\text { Manajemen diberikan }
$$

fleksibilitas dalam memilih metode akuntansi yang akan digunakan salah satunya dengan menerapkan prinsip konservatisme akuntansi. Watts (2003) mendefinisikan konservatisme sebagai tindakan manajemen dengan lebih lambat mengakui laba atau pendapatan.

Bila prinsip ini diterapkan maka akan menyebabkan angka laba dan pendapatan cenderung rendah sedangkan angka biaya cenderung tinggi. Basu (1997) menginterpretasikan konservatisme sebagai kecenderungan akuntan untuk mengakui good news sebagai keuntungan dibanding mengakui bad news sebagai kerugian. 
Prinsip konservatisme akuntansi menjadi kontroversial karena terdapat banyak kritik yang muncul atas penerapan prinsip ini, namun ada pula pihak yang mendukung (Mayangsari dan Wilopo, 2002). Pihak yang menentang prinsip konservatisme berpendapat bahwa dengan diterapkannya prinsip konservatisme akuntansi dalam menyusun laporan keuangan maka akan dapat menghasilkan laporan keuangan yang cenderung bias karena tidak mencerminkan kondisi keuangan perusahaan yang sesungguhnya (Kiryanto dan Supriyanto, 2006). Namun disisi lain pihak yang mendukung prinsip konservatisme berpendapat bahwa dengan diterapkannya prinsip konservatisme akuntansi dalam menyusun laporan keuangan maka akan dapat bermanfaat untuk menghindari perilaku oportunistik manajer yang hendak memanipulasi laba (Fala, 2007).

Terlepas dari perdebatan tersebut, prinsip akuntansi konservatif masih dipakai. Adapun alasan prinsip ini masih dipergunakan adalah karena kecenderungan untuk melebih-lebihkan laba dalam pelaporan keuangan dapat dikurangi dengan menerapkan sikap pesimisme untuk mengimbangi optimisme yang berlebihan dari manajer. Selain itu laba yang disajikan terlalu tinggi (overstatement) lebih berbahaya daripada penyajian laba yang rendah (understatement) karena resiko tuntutan hukum yang didapat akan lebih besar bila menyajikan laporan keuangan dengan laba yang jauh lebih tinggi dari sesungguhnya (Dyahayu, 2012).

Teori akuntansi positif menyebutkan bahwa manajer akan cenderung mengurangi tingkat konservatisme akuntansi apabila perusahaan mengalami tingkat kesulitan keuangan (financial distress) yang tinggi (Suprihastini dan Pusparini, 2007). Financial distress dapat mendorong pemegang saham untuk mengganti manajer perusahaan karena manajer dianggap tidak mampu mengelola perusahaan dengan baik. Hal tersebut akan dapat mendorong manajer untuk merubah laba yang menjadi salah satu tolak ukur kinerja manajer dengan jalan mengatur tingkat konservatisme akuntansi. Apabila suatu perusahaan tidak memiliki masalah keuangan, 
manajer tidak akan menghadapi tekanan pelanggaran kontrak. Sehingga financial distress yang semakin tinggi akan mendorong manajer untuk menyajikan laporan keuangan yang tidak konservatif (Lo, 2005).

\section{Konservatisme akuntansi}

didorong untuk mengurangi atau menunda pajak dan untuk menghindari regulasi (Lasdi, 2008). Dalam teori akuntansi positif terdapat 3 hipotesis yaitu hipotesis bonus plan, hipotesis kovenan utang, dan hipotesis biaya politis. Hipotesis biaya politis memprediksi bahwa manager ingin mengecilkan laba untuk mengurangi biaya politis yang potensial (Watts dan Zimmerman, 1986). Perusahaan dengan size besar cenderung akan menerapkan prinsip konservatisme akuntansi agar laba yang dihasilkan tidak terlalu tinggi guna menghindari beban pajak yang tinggi akibat laba yang tinggi (Lo, 2005).

Leverage merupakan rasio yang menunjukkan seberapa besar hutang atau modal membiayai aktiva perusahaan Berdasarkan teori agensi, terdapat hubungan keagenan antara manajer dan kreditor. Manajer yang ingin mendapatkan kredit akan mempertimbakan rasio leverage (Dyahayu, 2012). Hasil penelitian Sari dan Adhariani, (2009) menunjukkan bahwa rasio leverage yang semakin besar akan cenderung mendorong perusahaan mengatur laba dan menyajikan laporan keuangan yang cenderung tidak konservatif.

Penelitian yang mengenai prinsip konservatisme ini menghasilkan temuan yang banyak ragamnya. Ningsih (2013) menjabarkan bahwa kesulitan keuangan perusahaan (financial distress) tidak berpengaruh pada konservatisme akuntansi. Nathania (2012) menemukan tingkat kesulitan keuangan berpengaruh positif pada konservatisme akuntansi, dan tingkat hutang (leverage) tidak berpengaruh pada konservatisme akuntansi. Yustina (2012) menjelaskan bahwa ukuran perusahaan, dan piutang berpengaruh signifikan terhadap tingkat konservatisme akuntansi.

Hipotesis dalam penelitian ini yaitu: H1 : Financial distress berpengaruh negatif pada konservatisme akuntansi. 
H2 : Ukuran perusahaan berpengaruh positif pada konservatisme akuntansi. H3 : piutang berpengaruh negatif pada konservatisme akuntansi.

\section{METODE PENELITIAN}

Konservatisme akuntansi sebagai variabel terikat dihitung dengan model akrual Givoly dan Hayn (2000), yang juga digunakan oleh Ratnadi et al. (2013). Alasan menggunakan model akrual adalah karena penelitian ini lebih memfokuskan pembahasan konservatisme dalam kaitannya dengan laba rugi, bukan mengenai reaksi pasar, sehingga model akrual tepat digunakan.

Konservatisme akuntansi diukur dengan akrual total dikurangi arus kas aktivitas operasi dideflasi dengan aset akhir tahun. Variabel pengukuran konservatisme akuntansi ini diberi istilah tingkat konservatisme akuntansi dan akan bernilai negatif jika perusahaan menerapkan konservatisme akuntansi.

Agar tingkat konservatisme akuntansi perusahaan mencerminkan nilai makin tinggi makin konservatif, maka hasil perhitungan tingkat konservatisme dikalikan dengan minus satu (-1) (Ratnadi et al., 2013). Adapun formulanya yaitu:

ConAcc $=$ TAAC $_{i t}-\mathrm{AKO}_{\text {it }}$

$\mathrm{A}_{\text {it }}$

Financial distress (X1) sebagai variabel bebas diukur dengan model

Altman (Z-score). Hasil penelitian Anggreani (2003) menunjukkan bahwa model

Altman merupakan model prediksi financial distress yang terbaik. Maka dari itu,

financial distress dalam penelitian ini diukur dengan model Altman. Adapun formulanya yaitu:

$\mathrm{Z}=6,56(\mathrm{~F} 1)+3,26(\mathrm{~F} 2)+6,72(\mathrm{~F} 3)+$ $1,05(\mathrm{~F} 4)$

Keterangan:

F1 = Modal Kerja dibagi dengan Total Aset

F2 = Laba Ditahan dibagi dengan Total Aset

F3 = Laba Sebelum Bunga dan Pajak dibagi dengan Total Aset F4 = Nilai Pasar Modal Sendiri dibagi dengan Total Hutang 
Dimana nilai $\mathrm{Z}$ dikategorikan sebagai berikut :

$\mathrm{Z} \geq 2,60=$ Tidak mengalami kebangkrutan $2,59 \geq Z \geq 1,11=$ Raguragu

$\mathrm{Z} \leq 1,10=$ Mengalami kebangkrutan

Ukuran perusahaan (X2) diukur dengan

Log Total Aset. piutang (X3) diukur dengan Debt to Asset Ratio (DAR) yaitu Total debt/Total asset.

Jenis data kuantitatif dan sumber data sekunder digunakan dalam penelitian ini. Data diperoleh dari website BEI dan Indonesian Capital Market Directory (ICMD). Metode observasi non partisipan merupakan metode pengumpulan data yang digunakan.

Teknik stratified random sampling digunakan untuk penentuan sampel dimana merupakan pengambilan sampel yang dibagi menurut strata tertentu (Sugiyono, 2010:118). Sampel dihitung menggunakan rumus slovin dengan batas tertinggi kesalahan 5 persen. Setelah dihitung dengan rumus slovin maka diperoleh jumlah sampel sebanyak 241 tahun perusahaan. Sampel ini kemudian dibagi ke dalam tiap-tiap jenis industri secara proporsional.
Teknik analisis regresi linear berganda digunakan dengan model dasar sebagai berikut:

$\mathrm{Y}=\alpha+\beta 1 \mathrm{X} 1+\beta 2 \mathrm{X} 2+\beta 3 \mathrm{X} 3+\varepsilon$

Dimana :

Y

$\alpha$

$\begin{array}{lllll}\beta 1 & - & \beta 3 & \mathrm{X} 1\end{array}$

$\mathrm{X} 2$

X3

$\varepsilon$

: Konservatisme akuntansi : Nilai intersep konstanta

: Koefisien regresi variabel : Financial

Distress

: Ukuran Perusahaan

: piutang

: Error atau variabel di luar model

\section{HASIL DAN PEMBAHASAN}

Sebelum melakukan perhitungan analisis regresi linier sederhana maka dilakukan uji asumsi klasik, yaitu:

1) Uji Normalitas, diperoleh nilai K-S adalah 0,12 dan nilai Asymp. Sig. (2tailed) sebesar 0,32 yang menunjukkan lebih besar dari $\alpha=0,05$, hal ini berarti data residual berdistribusi normal. 
2) Uji Multikolinearitas, tidak ada variabel independen yang memiliki nilai tolerance kurang dari 0,10 dan dilihat dari perhitungan nilai VIF menunjukkan tidak ada variabel yang memiliki nilai VIF yang lebih dari 10. Hal ini berarti bahwa tidak ada korelasi antar variabel independen.

3) Uji Heteroskedastisitas, menunjukkan bahwa dalam penelitian ini tidak terjadi heteroskedastisitas, dilihat dari tingkat signifikansi untuk semua variabel indepeden di atas 0,05 ( $\operatorname{sig}>\alpha=5 \%)$.

4) Uji Autokorelasi, menunjukkan nilai DW sebesar 1,804. Dengan jumlah data $(\mathrm{n})=241$ dan jumlah variabel bebas $(\mathrm{k})$ $=3$ serta $\alpha=5 \%$ diperoleh angka $\mathrm{dl}=1,73$ dan $\mathrm{du}=1,79$. Karena DW sebesar 1,804 terletak antara batas atas (du) dan (4-du), maka dapat disimpulkan dalam model regresi ini tidak terdapat autokorelasi.

Setelah lolos pengujian asumsi klasik, maka dilanjutkan dengan analisis regresi linear berganda. Berdasarkan perhitungan nilai adjusted $\mathrm{R}^{2}$ model regresi sebesar 0,633 artinya bahwa 63,3 persen variasi (naik-turunnya) konservatisme akuntansi dipengaruhi oleh financial distress, ukuran perusahaan, dan piutang, sisanya sebesar 36,7 persen dipengaruhi oleh variabel lain. Nilai sig. Fhitung $=0,000$ $<\alpha=0,05$. Artinya, financial distress, ukuran perusahaan, dan piutang layak digunakan untuk memprediksi konservatisme akuntansi.

Hasil uji $t$ untuk variabel financial distress menunjukkan nilai thitung sebesar $-17,872$ dengan nilai signifikan thitung $(0,000)<\alpha(0,05)$, hal ini berarti hipotesis 1 di dukung. Kondisi keuangan yang bermasalah diakibatkan oleh kualitas manajer yang buruk. Dengan tingginya financial distress manajer kemungkinan akan menghadapi tekanan pelanggaran kontrak. Tentunya dapat menjadi sebuah ancaman bagi manajer yang bersangkutan, sehingga manajer menggunakan prinsip konservatisme akuntansi dalam penyajian laporan keuangan untuk menghindari kemungkinan konflik dengan kreditur dan pemegang saham.

Dengan demikian financial distress (tingkat kesulitan keuangan) 
yang semakin tinggi maka laporan keuangan yang dihasilkan akan semakin tidak konservatif. Hasil penelitian ini mendukung teori akuntansi positif. Hasil penelitian ini juga mendukung penelitian Ningsih (2013), Setyaningsih (2008), Nugroho (2012), yang menjelaskan tingkat kesulitan keuangan berpengaruh signifikan terhadap konservatisme akuntansi.

Hasil uji t untuk variabel ukuran perusahaan menunjukkan nilai thitung sebesar 2,047 dengan nilai signifikan thitung $(0,042)<\alpha(0,05)$, hal ini berarti hipotesis 2 di dukung. Perusahaan besar akan bersikap pesimis dalam penyajian laporan keuangan dan cenderung lebih berhati-hati dalam penyelenggaraan akuntansinya. Hasil penelitian Almilia (2005) menunjukkan bahwa perusahaan yang memiliki size yang besar sangat rentan terhadap political cost, sehingga perusahaan yang memiliki size yang besar cenderung menyajikan laporan keuangan yang cenderung konservatif. Hasil penelitian ini juga sejalan dengan penelitian Lasdi (2008), Lo (2005), Sari dan Adhariani (2009).
Hasil uji $t$ untuk variabel leverage menunjukkan nilai thitung sebesar -2,793 dengan nilai signifikan thitung $(0,000)<\alpha(0,05)$, hal ini berarti hipotesis 3 di dukung. Besarnya rasio leverage mengindikasikan kondisi perusahaan tidak begitu baik, sehingga manajer cenderung untuk meningkatkan laba agar kondisi keuangan terlihat baik oleh kreditur. Hal tersebut menunjukkan semakin tinggi leverage maka laporan keuangan yang dihasilkan akan semakin tidak konservatif. Hasil penelitian Sari dan Adhariani, (2009) menunjukkan bahwa rasio leverage yang semakin besar akan cenderung mendorong perusahaan mengatur laba dan menyajikan laporan keuangan yang cenderung tidak konservatif. Hasil ini sejalan dengan Widyaningrum (2008), Yustina (2012).

\section{KESIMPULAN}

Berdasarkan hasil analisis data dan pembahasan yang telah dilakukan pada bab sebelumnya maka dapat dsimpulkan bahwa:

1) Financial distress berpengaruh negatif pada konservatisme akuntansi 
perusahaan manufaktur yang terdaftar di BEI.

2) Ukuran perusahaan berpengaruh positif pada konservatisme akuntansi perusahaan manufaktur yang terdaftar di BEI.

3) Leverage berpengaruh negatif pada konservatisme akuntansi perusahaan manufaktur yang terdaftar di BEI.

\section{DAFTAR PUSTAKA}

Almilia, L.S. 2005. Teknik Pengujian Size Hypothesis dan Debt / Equity Hypothesis yang Mempengaruhi Tingkat Konservatisme Laporan Keuangan Perusahaan dengan Teknik Analisis Multinominal Logit. Jurnal Bisnis dan Akuntansi. STIE Perbanas. Surabaya.

Altman, E. 1960. Financial Ratios, Discriminant Analysis and the Prediction of Corporate Bankruptcy. Journal of Finance.

Anggreani. 2003. Pemilihan Prediktor Delisting Terbaik (Perbandingan antara The Zmijewski Model, The Altman Model, dan The springate Model). Fakultas Ekonomi Universitas Islam Indonesia.

Basu, Sudipta. 1997. The Conservatism Principle and the Asymmetric Timeliness of Earnings. Journal of Accounting and Economics. Vol 24 No. I

Dyahayu Artika Deviyanti. 2012. Analisis Faktor-Faktor yang Mempengaruhi Penerapan
Konservatisma dalam Akuntansi. Skripsi. Fakultas Ekonomika dan Bisnis Universitas Diponegoro. Semarang.

Fala, Dwi Yana Amalia. 2007. Pengaruh Konservatisme Akuntansi terhadap Penilaian Ekuitas Perusahaan dimoderasi oleh Good Corporate Governance.Makalah Simposium Nasional Akuntansi X. Makassar.

Ghozali, Imam. 2006. Aplikasi Analisis Multivariate dengan program SPSS. Semarang : Universitas Diponegoro.

Givoly, Dan Carla Hayn. 2002. Risisng Conservatism: Impliocations for financial Analysis.AIMR. January/February.

Ningsih, E. 2013. Pengaruh Tingkat Kesulitan Keuangan dan Risiko Litigasi terhadap Konservatisme Akuntansi.

Nugroho, Deffa Agung dan Siti Mutmainah. 2012. Pengaruh Struktur Kepemilikan Manajerial, Debt Covenant, Tingkat Kesulitan Keuangan Perusahaan, Dan Risiko Litigasi Terhadap Konservatisme Akuntansi. Skripsi. Fakultas Ekonomika dan Bisnis Universitas Diponegoro. Semarang.

Penman, Stephen H. dan Xiao-Jun Zhang. 2001. Accounting Conservatism, The Quality of Earnings, and Stock Returns. Working paper. School of Business Columbia University dan Haas School of Business University of California.

Ratna Dewi, A.A.A. 2004. Pengaruh Konservatisma Laporan Keuangan Terhadap Earnings Response 
Coefficient. Jurnal Riset Akuntansi Indonesia 7(2) h:207-223.

Sugiyono. 2010. Metode Penelitian Bisnis. Bandung : CV. Alfabeta.

Suprihastini, Eka dan Herlina Pusparini. 2007. Pengaruh Tingkat Kesulitan Keuangan dan Tingkat Hutang Terhadap Konservatisme Akuntansi pada Perusahaan manufaktur yang Terdaftar di Bursa Efek Jakarta 2001-2005. Jurnal Riset Akuntansi. Vol 6.

Watts, Ross. 2003. Conservatism in Accounting Part I: Explanations and Implications. Working paper. Simon School of Bisnis, University of Rochester.

Watts R. and J.L. Zimmerman. 1986. Positive Accounting Theory. New York: Prentice-Hall.

Widyaningrum. 2008. Pengaruh Kepemilikan Manajerial, Leverage dan Risiko Litigasi terhadap Konservatisme Akuntansi. Skripsi. Undip.

Yustina, Reny. 2012. Pengaruh Konvergensi IFRS Dan Mekanisme Good Corporate Governance Terhadap Tingkat Konservatisme Akuntansi. Skripsi. Fakultas Ekonomi dan Bisnis Universitas Brawijay 
Jurnal Parameter, Volume 3, No. 1 (2018)

ISSN : 1979-8865 